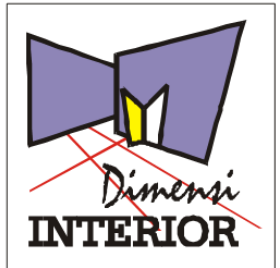

http://dimensiinterior petra. id

\title{
Kajian Antropometri \& Ergonomi Desain Mebel Pendidikan Anak Usia Dini 3-4 Tahun di Siwalankerto
}

\author{
Jennie Hasimjaya | Mariana Wibowo | Dodi Wondo \\ Program Studi Desain Interior, Universitas Kristen Petra, Surabaya \\ Email: lidya_jennie@yahoo.com
}

\begin{abstract}
ABSTRAK
Mebel merupakan fasilitas dalam ruang yang sangat vital dalam mendukung tercapainya produktivitas dari aktivitas yang dilakukan. Aktivitas belajar anak usia dini biasanya cenderung banyak berinteraksi dengan mebal sebagai fasilitas belajarnya. Sebagai studi kasus adalah mebel fasilitas belajar di komunitaspendidikan anak usia dini di Siwalakerto. Mebel anak usia dini di Siwalankerto perlu dikaji kesesuaiannya secara antropometri dan ergonomi untuk dapat digunakan dengan nyaman, terutama untuk anak usia 3-4 tahun yang aktivitas belajarnya lebih banyak dan lebih sering berinteraksi dengan mebel. Penelitian ini bertujuan untuk mendapatkan antropometri anak usia dini 3-4 tahun yang dapat direkomendasikan untuk menentukan ukuran mebel yang ergonomis dengan pengguna sehingga dapat mengoptimalkan kenyamanan dan menghindari munculnya kelainan dikarenakan kesalahan serta ketidak sesuaian dalam menggunakan mebel. Penelitian ini menggunakan metode kuantitatif format eksplanasi survey. Hasil dari penelitian ini adalah ukuran tubuh dari anak- anak paud Siwalankerto usia 3-4 tahun dan ukuran mebel yang direkomendasian sesuai berdasarkan data ukuran antropometri tersebut.
\end{abstract}

Kata Kunci: mebel, antrophometri, ergonomi.

\section{ABSTRACT}

Furniture is a facility in indoor space that is very vital in supporting the achievement of productivity from activities carried out. Learning activities of early childhood usually tend to interact a lot thickly as learning facilities. As a case study, furniture is a learning facility in the early childhood education community in Siwalakerto. Early childhood furniture at Siwalankerto needs to be assessed for its anthropometric and ergonomic suitability to be used comfortably, especially for children aged 3-4 years whose learning activities are more and more often interact with furniture. This study aims to obtain anthropometry of children aged 3-4 years who can be recommended to determine the size of furniture that is ergonomic with users so as to optimize comfort and avoid the appearance of abnormalities due to errors and incompatibility in using furniture. This study uses a quantitative method of survey explanation format. The results of this study are the body sizes of Siwalankerto children aged 3-4 years and recommended furniture sizes according to the data on the size of the anthropometry.

Keywords: furniture, anthropometry, ergonomics.

\section{PENDAHULUAN}

Manusia beraktivitas akan selalu terkait dengan fasilitas yang ada di sekitar lingkungan mereka untuk menunjang dan mewadahi segala aktivitas mereka yang bertujuan supaya aktivitas mereka dapat berjalan lancar dan menjadi lebih mudah termasuk juga anak-anak. Terutama anak usia dini dimana masa ini merupakan masa yang genting dikarenakan masa ini merupakan masa anak sangat peka terhadap segala informasi [1].

Karen hal tersebut, maka pemerintah membuat sebuah program untuk anak usia dini supaya bisa mendapatkan pembelajaran sejak dini dan membantu anak dengan ekonomi yang lemah sehingga dapat melanjutkan pendidikan tanpa biaya yang berat. Program tersebut adalah pendidikan anak usia dini yaitu merupakan sebuah metode yang ditujukan untuk anak usia dini dalam membantu merangsang dari bidang pendidikan, baik dari segi jasmani dan rohani sehingga anak dapat melanjutkan ketahap yang lebih tinggi dan kehidupan tahap berikutnya [2].

Program ini merupakan program pemerintah sehingga dana yang diberikan cukup terbatas terutama untuk pembuatan mebel, sehingga seringkali pengadaan mebel hanya berdasar harga yang terbatas. Keterbatasan ini mengakibatkan pertimbangan hanya sebatas harga yang sesuai, dan kurang mempertimbangkan kesesuaian dimensi tubuh pengguna, sehingga tidak ergonomis 
apabila digunakan dalam jangka waktu yang agak lama. Sementara itu, anak usia dini memiliki sifat yang energik, serta tidak dapat tenang atau berkonsentrasi secara lama apabila mebel yang digunakan tidak nyaman [3].

Terutama anak dengan umur yang lebih dewasa pasti semakin banyak memiliki aktivitas dalam belajar, sehingga karena hal inilah penting apabila mebel anak usia dini 3-4 tahun perlu dikaji berdasarkan bidang ilmu ergonomi yaitu melalui salah satu sub displin ilmunya yaitu antropometri dimana merupakan kumpulan data berupa angka yang berhubungan dengan karakteristik tubuh manusia, kekuatan, dan bentuk [4], yang nantinya dapat diterapkan kedalam pembuatan ukuran mebel anakanak tersebut.

Dimana mebel yang dikaji berdasarkan antropometri dan ergonomi merupakan mebel PAUD Siwalankerto yang meliputi PAUD Anggrek I, Anggrek III, Srikandi, Buyung Ceria, dan Mentari Pagi dikarenakan PAUD ini tidak memiliki acuan yang cukup akurat untuk ukuran sarana belajar mereka dan selain itu sering mendapatkan bantuan berupa mebel yang ternyata tidak sesuai dengan anak didik mereka. Sehingga karena hal inilah, perlunya dilakukan penelitian ini dimana mebel PAUD Siwalankerto perlu dikaji berdasarkan ergonomi dan antropometri sehingga nantinya dapat menentukan ukuran mebel yang ergonomis dan sesuai dengan pengguna karena desain yang baik itu tidak hanya berhenti pada hal yang bagus namun juga harus memiliki dampak yang positif terhadap pengguna atau dapat dikatakan menyelesaikan masalah pengguna [5].

Selain itu mengapa mebel penting dikaji berdasarkan 2 hal tersebut dikarenakan mebel merupakan salah satu fasilitas yang sangat sering berinteraksi dengan manusia dan dimana dalam penelitian ini sekolah merupakan tempat ke-2 setelah rumah masing-masing dimana anak banyak menghabiskan waktunya.

\section{METODE PENELITIAN}

\section{A. Pendekatan Penelitian}

Pendekatan penelitian yang digunakan dalam penelitian ini adalah kuantitatif eksplanasi survei yaitu dimana format ini memiliki tujuan untuk mempelajari sebuah data yang diambil dari sampel melalui populasi yang telah didapat sehingga nantinya dapat menemukan sebuah deskripsi yang menjelaskan tentang hubungan anatar variabel terkait dalam penelitian tersebut [6]. Pendekatan ini untuk menjelaskan variable terkait seperti umur dan jenis kelamin apakah mempengaruhi dalam perbedaan dimensi tubuh anak dan menyempurnakan sebuah teori yaitu antropometri anak usia dini 3-4 tahun di PAUD Siwalankerto. Penelitian yang dilakukan yaitu dengan mengukur seluruh variabel yang dibutuhkan yaitu antropometri anak usia 3-4 tahun yang kemudian dihitung dengan konsep persentil dan selanjutnya hasil tersebut digunakan untuk menentukan ukuran mebel yang ergonomis. Serta hasil ini dicocokan dengan data ukuran mebel dilapangan bahwa memang mebel di PAUD Siwalankerto tidak sesuai dengan anak didiknya sehingga ukuran yang dihasilkan dapat digunakan sebagai acuan.

\section{B. Populasi dan Sampel}

Sampel yang digunakan dalam penelitian ini adalah anak 3- 4 tahun PAUD Siwalankerto dengan jumlah sebesar 193 anak dimana terdiri dari 95 anak laki-laki dan 98 anak perempuan. Populasi yang digunakan merupakan populasi terbatas maksudnya adalah populasi yang memiliki batas secara kuantitatif yang jelas dikarenakan memiliki karakteristik tertentu [7]. Selain itu populasi dalam penelitian ini bersifat heterogen. Dikatakan heterogen karena memiliki karakteristik berbeda yaitu harus berumur 3-4 tahun dengan jenis kelamin perempuan dan laki-laki.

\section{Teknik Sampling}

Teknik sampling yang digunakan dalam penelitian ini adalah purposive sampling maksudnya merupakan sebuah teknik untuk menentukan sampel dengan pertimbangan tertentu dan lebih mengutamakan tujuan dari penelitian ini [8]. Pada penelitian ini dikatakan menggunakan purposive sampling karena peneliti memilih sampelnya berdasarkan pengamatan dan studi pendahuluan yang cukup mendalam sehingga dapat menentukan sampelnya yaitu anak usia dini 3-4 tahun di Siwalankerto karena anak usia dini 3-4 tahun itu lebih banyak berinteraksi dengan mebel dan lebih banyak memiliki aktivitas belajar dan dimana mebel di PAUD Siwalankerto itu tidak sesuai dengan penggunannya.

\section{Metode Pengumpulan Data}

Dalam penelitian ini mengumpulkan data dengan cara observasi langsung yaitu dimana peneliti berada di tempat yang sama dan melihat secara langsung objek yang akan diteliti. Dalam penelitian ini, peneliti mendatangi PAUD Siwalankerto selama masa penelitian dan melakukan wawancara secara terstruktur yaitu pertayaannya telah disediakan dan disusun terlebih dahulu oleh peneliti apa saja yang akan ditanyakan sehingga lebih mudah dalam mengingat dan untuk menghindari tertinggal apa yang akan diteliti dan menjadi kurang informasi [9]. Dalam penelitian ini, pertanyaan telah disusun secara terstruktur terlebih dahulu sebelum melakukan penelitian sehingga tidak ada yang luput dalam proses wawancara nantinya. Dimana pertanyaan tersebut seputar data tentang PAUD Siwalankerto serta tentang permasalahan mebel yang ada di sana.

\section{E. Metode Pengolahan Data}

Pertama yang dilakukan adalah melakukan proses editing yaitu merupakan proses pemeriksaan kembali catatan yang ada untuk memastikan apakah jawaban yang didapat telah cukup baik dan dapat untuk dilanjutkan ketahap berikutnya. Setelah ini melakukan proses koding dimana peneliti mengklasifikasikan hasil penelitian berdasarkan karakteristik sampel yang ada [10]. Dan kemudian melakukan proses tabulasi yaitu proses dimana data dimasukkan dan disusun di dalam tabel yang berisikan sesuai dengan data yang didapat dan sesuai dengan kebutuhan analisis [11]. Selain itu dianalisis menggunakan konsep persentil dan membandingkan mebel di lapangan dengan hasil 
perhitungan persentil yang digunakan untuk mengetahui bahwa mebel tersebut tidak ergonomi dan hasil persentil yang didapat berdasarkan penelitian dapat digunakan untuk menentukan ukuran mebel yang ergonomis.

\section{KAJIAN PUSTAKA}

\section{A. Antropometri}

Antropometri dapat diartikan secara jelas yaitu merupakan suatu ilmu yang berkaitan secara khusus menyangkut dimensi tubuh manusia [12].

\section{B. Metode Pengukuran Tubuh}

\section{Dimensi Statis}

Dimensi statis merupakan pengukuran yang terkait dengan pengukuran dimensi tubuh manusia dalam keadaan diam atau dalam posisi yang dibakukan. Contohnya seperti tinggi badan, panjang lengan, tinggi siku, tebal paha, tinggi mata duduk dan sebagainya [13] seperti di bawah ini :

a. Tinggi siku berdiri (Tsb)

Dimensi ini digunakan untuk merancang ketinggian maksimum permukaan meka kerja dalam posisi berdiri. Konsep dari pengguna dimensi juga menuntut agar subjek terpendek yang menggunakan fasilitas tersebut dapat menggunakan fasilitas itu secara nyaman tanpa harus mengangkat siku dalam menggunakannya [14].

b. Tinggi pinggul (Tp)

Dimensi ini digunakan untuk menentukan ketinggian maksimum sebuah fasilitas mencuci tangan dengan konsep yang sama dimana menuntut bahwa subjek terpendek harus dapat menggunakan secara nyaman [14]. c. Tinggi mata duduk (Tmd)

Dimensi ini digunakan untuk merancang ketinggian maksimum jarak pandang mata secara horizontal untuk melihat objek yang tertangkap oleh mata.

d. Tinggi siku duduk (Tsd)

Dimensi ini digunakan untuk menentukan ketinggian sandaran lengan pada sebuah kursi . Dimana subjek yang memiliki ukuran terpendek harus dapat meletakkan tangan secara nyaman.

e. Tinggi bahu duduk (Tbd)

Dimensi ini digunakan untuk merancang ketinggian sebuah fasilitas desain untuk mewadahi ketinggian bahu secara menyeluruh. Dimana konsep yang diterapkan dalam dimensi ini mengharuskan subjek dengan ukuran tertinggi harus merasa nyaman dalam menggunakan fasilitas tersebut.

f. Tinggi popliteal (Tpo)

Dimensi ini biasa digunakan untuk menentukan ketinggian maksimum permukaan tempat duduk. Tinggi tempat duduk yang dirancang diusahakan agar orang yang mempunyai tinggi popliteal terendah dapat menggunakan kursi tersebut dengan nyaman.

g. Tinggi lulut (Tl)

Dimensi ini dirancang untuk menentukan ketinggian permukaan meja bagian bawah dan dimensi ini mengutamakan agar orang dengan ukuran yang paling tinggi dapat menggunakan meja secara nyaman karena ruang kaki yang cukup longgar [14].

h. Panjang paha (Pp)

Dimensi ini digunakan untuk menentukan jarak anatar kursi satu dengan kursi lainnya serta perlu ditambah kelonggaran supaya dapat diakses keluar masuk. Dimana dalam dimensi ini menuntut agar subjek dengan ukuran terpanjang dapat mengakses jarak tersebut.

i. Panjang popliteal-pantat (Ppp)

Dimensi ini digunakan untuk merancang panjang alas kursi. Dalam dimensi ini panjang alas duduk tidak boleh melebihi panjang dari popliteal pantat yang paling pendek.

j. Lebar bahu (Lb)

Dimensi ini digunakan untuk merancang lebar sandaran kursi dimana diharapkan dengan menggunakan ukuran ini orang dengan bahu paling lebar dapat menggunakan fasilitas ini secara nyaman.

k. Lebar pinggul (Lp)

Kegunaan dari dimensi ini salah satunya adalah untuk menentukan lebar alas duduk dengan pertimbangan orang dengan pinggul yang paling lebar dapat duduk di kursi tersebut.

1. Jangkauan vertikal duduk (Jvd)

Kegunaan dari dimensi ini adalah dapat digunakan untuk merancang tinggi maksimum sebuah fasilitas atau sarana pendukung aktivitas manusia agar mudah dijangkau terutama subjek dengan jangkuan terpendek dalam posisi duduk [14].

m. Jangkauan vertikal berdiri (Jvb)

Dimensi ini digunakan untuk merancang tinggi maksimum untuk menggapai fasilitas pendukung aktivitas manusia. Dimana subjek dengan jangkauan terpendek tetap dengan mudah dapat menjangkau.

n. Jangkauan horizontal duduk (Jhd) dan jangkauan

horizontal berdiri (Jhb)

Dimensi ini digunakan untuk menentukan jarak jangkuan fasilitas agar mudah dijangkau terutama oleh subjek dengan jangkauan yang paling pendek [14].

o. Berat Badan (Bb)

Dimensi ini digunakan untuk menentukan kekuatan minimum sebuah kursi. Dimana dikatakan dalam menentukan menggunakan dimensi ini maka berat badan yang paling beratlah harus dipertimbangkan [15]. p. Menentukan nilai persentil

Dalam menentukan nilai persentil, pedoman yang digunakan adalah jenis dimensi, yang terdiri dari :

- Dimensi jangkauan

Yaitu penentuan dimensi dimana orang yang paling kecil dalam populasi dapat menggunakan perancangan tersebut. Dimensi jangkuan ini ditujukan untuk mengakomodasi jenis aktivitas yang sifatnya jangkuan baik yang dilakukan lengan maupun kaki. Contohnya seperti tinggi kursi.

- Dimensi ruang

Merupakan kebalikan dari dimensi jangkuan karena pada dimensi ruang diharapkan dimana orang dengan ukuran paling besar dalam populasi pengguna dapat menggunakan rancangan. Perancangan dengan sifat dimensi ruang ini ditujukan untuk orang yang memiliki ukuran yang paling tinggi dan paling gemuk [14].

\section{Ergonomi}

Ergonomi dapat diartikan sebagai ilmu yang menyangkut tentang keselamatan, kenyamanan manusia 
di tempat kerja, di rumah, di sekolah dan tempat manapun yang menuntut manusia berinteraksi dengan lingkungan sekitar dengan tujuan utama untuk manusia dapat menyesuaikan dengan lingkungan sekitarnya [12].

\section{Furniture Anak Usia Dini}

Furniture anak usia dini yang ergonomis meliputi :

a. Meja yang ergonomis sebaiknya tidak bertekstur karena dapat membahayakan pengguna yaitu anak tersebut dan dapat mengganggu belajar mengajar anak karena hasil dari tugas belajar tersebut tidak dapat maksimal [16].

b. Kursi yang nyaman seharusnya memiliki lebar dudukan melebihi dari paha seseorang [17].

c. Kursi dapat dikatakan ergonomis apabila alas duduknya sesuai dengan lebar pantat pengguna [18].

d. Meja baru dapat dikatakan nyaman digunakan apabila pada permukaan meja bagian bawah memiliki ruang untuk ketebalan paha pengguna 19].

e. Untuk meja belajar supaya ergonomis maka menyesuaikan dengan kursinya. Kemudian ketinggian permukaan bawah meja harus lebih di atas permukaan dudukan kursi sekitar kurang lebih $21 \mathrm{~cm}$.

f. Telapak kaki anak harus menyentuh lantai secara penuh sehingga dapat beraktivtas dan menyesuaikan dengan mebel yang digunakan secara nyaman dan santai karena kaki tidak perlu menggantung dan mengalami pegal.

g. Dalam posisi duduk, lutut harus membentuk posisi melengkung dengan sudut kurang lebih $90^{\circ}$ [3].

\section{HASIL DAN DISKUSI}

Penelitian ini membahas tentang antropometri anak PAUD Siwalankerto usia 3-4 tahun yang nantinya dapat digunakan untuk menentukan ukuran sarana pembelajaran yang sesuai dengan anak paud tersebut. Berdasarkan hasil dari analisa desain mebel di 5 PAUD Siwalankerto adalah:

1. Beberapa meja yang ada di PAUD siwalankerto khususnya untuk anak usia 3-4 tahun ternyata memiliki gambaran mural di atas meja tersebut sehingga ini menyebabkan anak menjadi tidak nyaman dalam menggunakan meja tersebut dikarenakan hasil dari tugas yang dikerjakan tidak maksimal. Padahal disebutkan bahwa meja yang ergonomis itu sebaiknya tidak bertekstur karena akan membahayakan pengguna dan mengganggu aktivitas belajarnya [17].

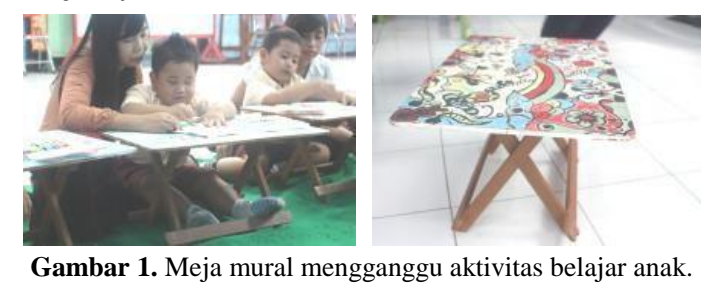

2. Pada PAUD di Siwalankerto beberapa menggunakan meja lipat untuk menghemat tempat dan mempersingkat waktu untuk meringkas namun permasalahannya adalah adanya bracing pada kaki meja tersebut yang mengganggu posisi kaki anak pada saat duduk karena tidak dapat memasukkan kaki di bawah permukaan meja. Padahal dikatakan bahwa meja yang ergonomis itu harus memiliki untuk ketebalan paha sehingga lebih nyaman [19].

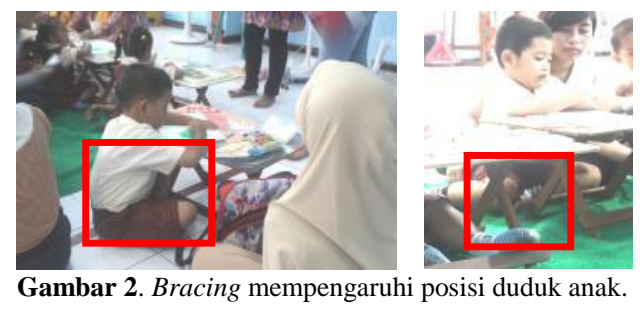

3. Ketinggian dari meja yang ada di lapangan tidak sesuai dengan pengguna dimana terlalu tinggi menyebabkan anak yang menggunakan harus berlutut supaya dapat melihat dengan nyaman tugas yang dikerjakan. Seharusnya tinggi meja disesuiakan dengan ukuran pengguna karena meja yang ergonomis itu diseuaikan dengan pengguna [3].

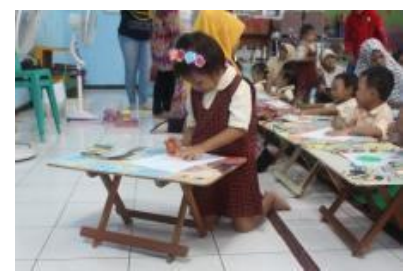

Gambar 3. Meja terlalu tinggi untuk pengguna.

4. Kursi yang digunakan kurang tinggi dari pada yang seharusnya. Karena data dilapangan menyatakan ukurannya adalah $18.5 \mathrm{~cm}$ seharusnya berdasarkan perhitungan adalah 21-22 $\mathrm{cm}$ padahal dikatakan bahwa kursi yang ergonomis seharusnya menyesuaikan dengan pengguna dimana saat pengguna duduk kakinya dapat membentuk sudut sekitar $90^{\circ}$ [3].

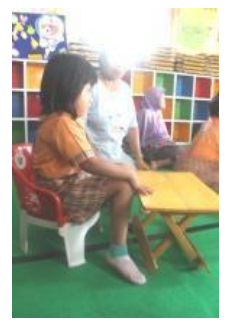

Gambar 4. Lutut tidak membentuk sudut $90^{\circ}$

5. Salah satunya kursi belajar dari kayu yang digunakan ternyata dimana lebar dudukannya tidak dapat mewadahi secara menyeluruh pantat anak. Seharusnya kursi yang nyaman itu apabila lebar alas duduknya disesuaikan dengan lebar pantat pengguna [18] dan lebih besar dari paha seseorang [17].

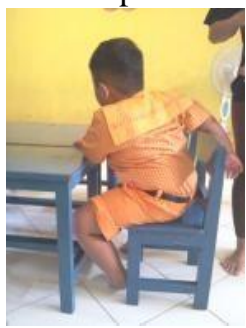

Gambar 5. Alas permukaan duduk yang kurang ergonomis. 
6. Untuk rak sepatu dan rak barang sudah cukup sesuai dengan pengunannya yaitu anak-anak usia 3-4 tahun karena anak sudah dapat menggapai rak paling atas secara mandiri. Namun permasalahannya adalah dimana rak tersebut tidak dapat mewadahi secara menyeluruh untuk anak 3-4 tahun di Siwalankerto.
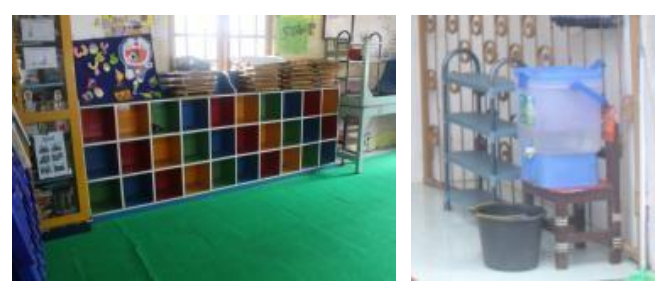

Gambar 6. Rak sepatu dan rak tas sudah cukup ergonomis.

Berdasarkan masalah yang telah dijabarkan di atas maka perlu dilakukan pengukuran antropometri anak PAUD Siwalankerto usia 3-4 tahun dengan jumlah sampel sebesar 193 orang anak. Berikut merupakan hasil persentil dari anak usia dini 3-4 tahun di Siwalankerto. Ukuran tersebut yang nantinya dapat digunakan sebagai pedoman menentukan ukuran mebel yang ideal.
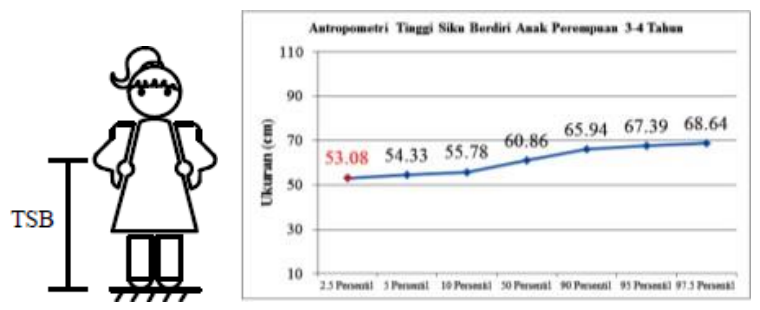

Gambar 7. Persentil tinggi siku berdiri anak perempuan 3-4 tahun.

Berdasarkan hasil perhitungan dari persentil tinggi siku berdiri seperti Gambar 7, dapat digunakan untuk menentukan alas permukaan meja dalam posisi berdiri dengan menggunakan hasil dari 2.5 persentil yaitu 53.08 $\mathrm{cm}$ supaya anak dengan tinggi siku yang paling pendek dapat meletakkan tangannya secara menyeluruh.

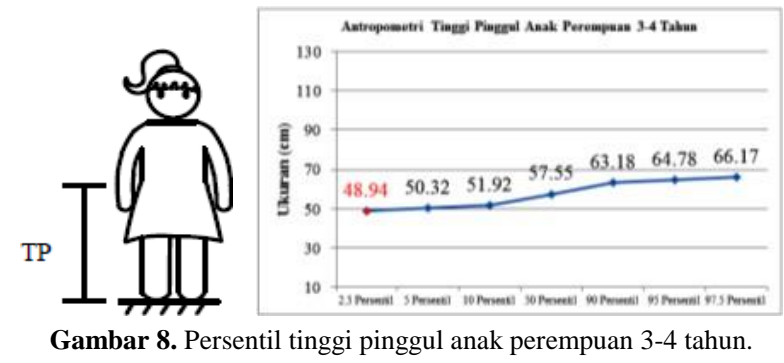

Berdasarkan hasil perhitungan dari persentil tinggi pinggul seperti pada Gambar 8, dapat digunakan untuk menentukan tinggi bak cuci tangan. Dapat menggunakan hasil dari 2.5 persentil yaitu $48.94 \mathrm{~cm}$ supaya anak dengan tinggi pinggul yang paling pendek dapat mencuci tangannya secara mandiri.
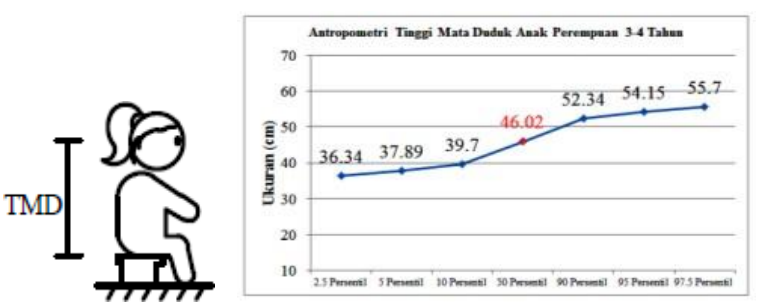

Gambar 9. Persentil tinggi mata duduk anak perempuan 3-4 tahun.

Berdasarkan hasil perhitungan dari persentil tinggi mata duduk anak seperti pada Gambar 9, dapat digunakan untuk jarak pandang mata secara horizontal. Dapat menggunakan hasil dari 50 persentil yaitu 46.02 $\mathrm{cm}$ supaya kedua belah kelompok dapat melihat secara nyaman dimana tidak terlalu tinggi atau rendah.
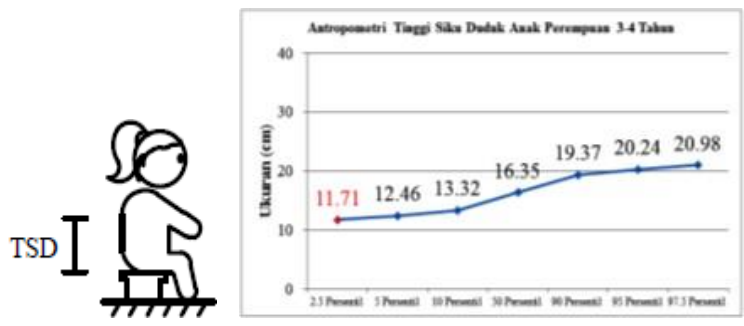

Gambar 10. Persentil tinggi siku duduk anak perempuan 3-4 tahun.

Berdasarkan hasil perhitungan dari persentil tinggi siku duduk seperti Gambar 10, digunakan untuk menentukan tinggi arm rest dengan menggunakan hasil dari 2.5 persentil yaitu $11.71 \mathrm{~cm}$ supaya anak dengan tinggi siku duduk yang paling rendah. Dapat meletakkan lengannya secara menyeluruh di atas arm rest.

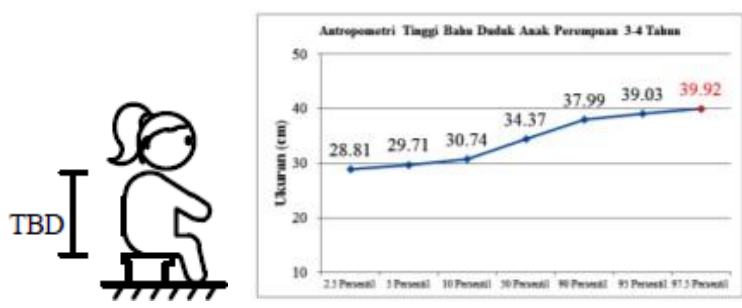

Gambar 11. Persentil tinggi bahu duduk anak perempuan 3-4 tahun.

Berdasarkan hasil perhitungan dari persentil tinggi bahu duduk seperti Gambar 11, dapat digunakan untuk menentukan tinggi sandaran sebuah kursi dengan menggunakan hasil dari 97.5 persentil yaitu $39.92 \mathrm{~cm}$ supaya anak yang memiliki bahu paling tinggi dapat bersandaran secara menyeluruh.
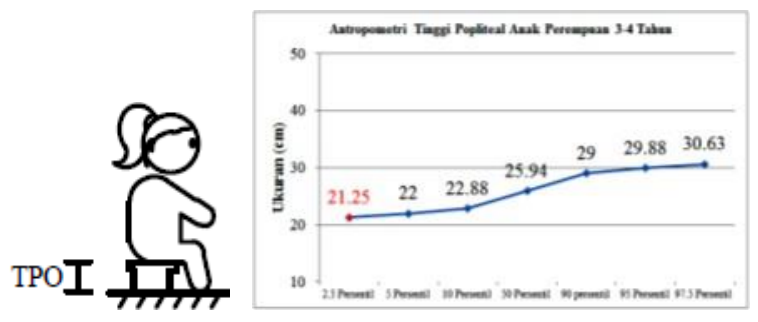

Gambar 12. Persentil tinggi popliteal anak perempuan 3-4 tahun.

Berdasarkan hasil perhitungan dari persentil tinggi popliteal Gambar 12, dapat digunakan untuk menentukan tinggi alas permukaan duduk. Menggunakan hasil dari 2.5 persentil yaitu $21.25 \mathrm{~cm}$ supaya anak dengan tinggi popliteal yang paling pendek, telapak kakinya dapat menyentuh lantai seutuhnya. 

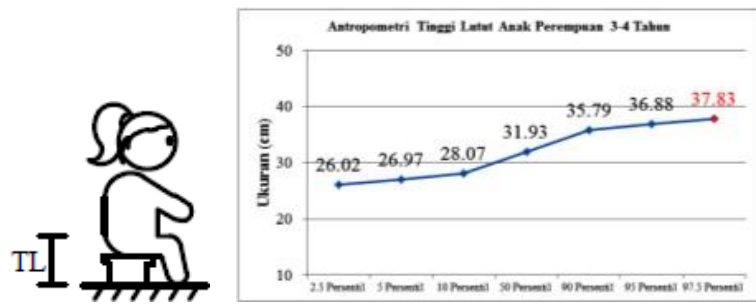

Gambar 13. Persentil tinggi lutut anak perempuan 3-4 tahun.

Berdasarkan hasil perhitungan dari persentil tinggi lutut seperti Gambar 13, dapat digunakan untuk menentukan tinggi permukaan meja bagian bawah. Menggunakan hasil dari 97.5 persentil yaitu $37.83 \mathrm{~cm}$ supaya anak dengan lutut yang paling tinggi tetap dapat memasukkan kaki mereka di bawah meja.
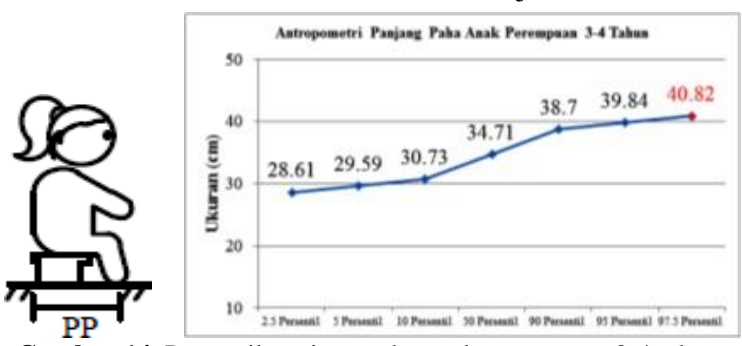

Gambar 14. Persentil panjang paha anak perempuan 3-4 tahun.

Berdasarkan hasil perhitungan dari persentil panjang paha seperti Gambar 14, dapat digunakan untuk jarak kursi satu dengan kursi lainnya dengan menggunakan hasil dari 97.5 persentil yaitu $40.82 \mathrm{~cm}$ supaya anak dapat meletakkan kaki mereka di jarak yang ada di antara kursi.
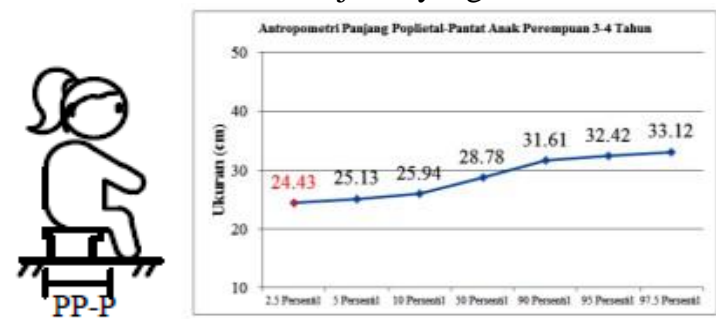

Gambar 15. Panjang popliteal-pantat anak perempuan 3-4 tahun.

Berdasarkan hasil perhitungan dari persentil panjang popliteal-pantat seperti Gambar 15, dapat digunakan untuk menentukan kedalam alas duduk. Menggunakan hasil dari 2.5 persentil yaitu $24.43 \mathrm{~cm}$ supaya anak dengan panjang popliteal-pantat yang paling pendek tetap dapat duduk dimana kakinya tidak menggantung.

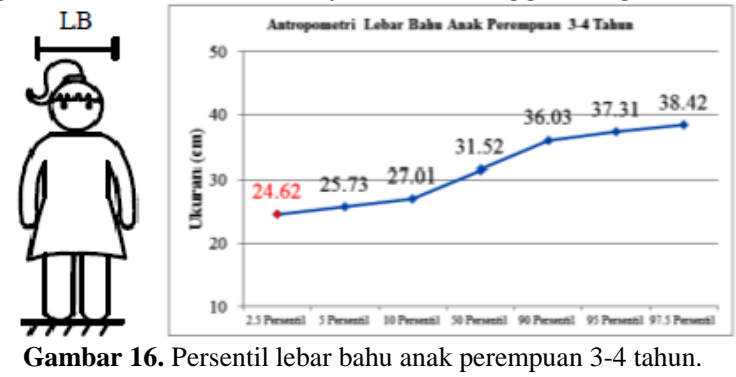

Berdasarkan hasil perhitungan dari persentil lebar bahu seperti pada Gambar 16, dapat digunakan untuk menentukan lebar sandaran kursi. Menggunakan hasil dari 97.5 persentil yaitu $38.42 \mathrm{~cm}$ supaya bahu paling lebar tetap dapat bersandar secara menyeluruh sehingga merasa nyaman.
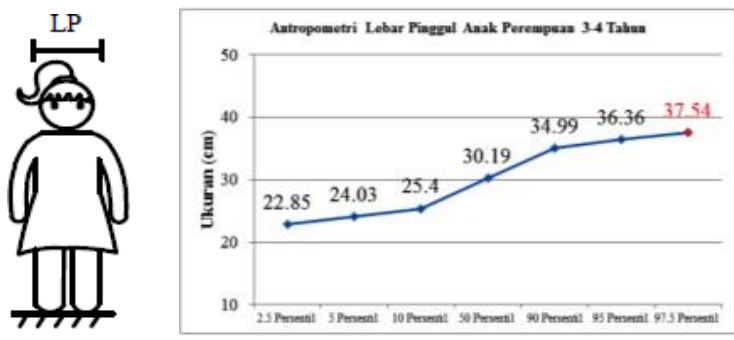

Gambar 17. Persentil lebar pinggul anak perempuan 3-4 tahun.

Berdasarkan hasil perhitungan dari persentil lebar bahu seperti pada Gambar 17, dapat digunakan untuk menentukan lebar alas duduk sebuah kursi. Menggunakan hasil dari 97.5 persentil yaitu $37.54 \mathrm{~cm}$ supaya anak dengan pinggul yang paling lebar dapat terwadahi dan nyaman.
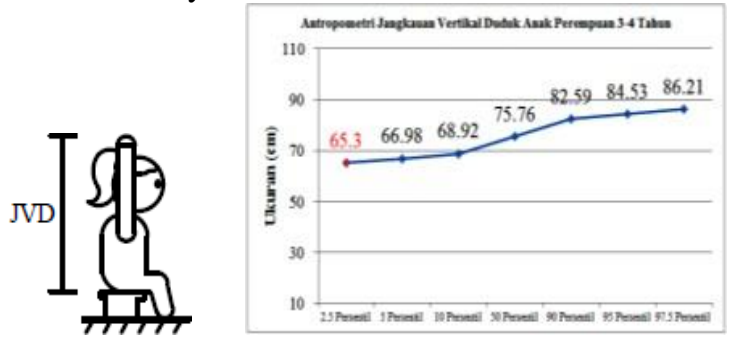

Gambar 18. Persentil jangkauan vertikal duduk anak perempuan 3-4 tahun.

Berdasarkan hasil perhitungan dari persentil jangkauan vertikal duduk seperti Gambar 18, dapat digunakan menentukan tinggi maksimal rak dimana digapai dalam posisi duduk. Menggunakan hasil dari 2.5 persentil yaitu $65.3 \mathrm{~cm}$ supaya anak dengan jangkauan terpendek dapat menjangkau rak paling atas.
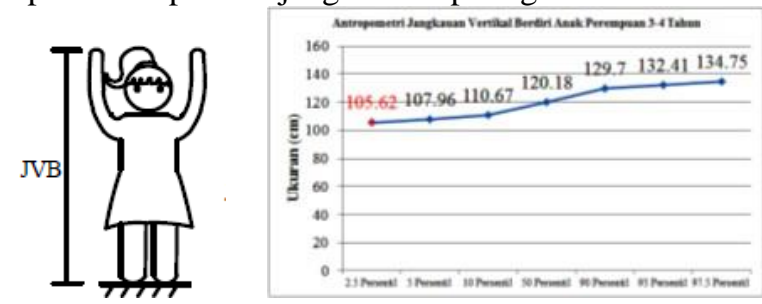

Gambar 19. Persentil jangkauan vertikal berdiri anak perempuan 3-4 tahun.

Berdasarkan hasil perhitungan dari persentil jangkuan vertikal berdiri seperti Gambar 19, dapat digunakan untuk menentukan tinggi maksimal sebuah rak. Menggunakan hasil dari 2.5 persentil yaitu $105.62 \mathrm{~cm}$ supaya yang memiliki jangkauan paling pendek dapat menjangkau sendiri rak yang paling atas.
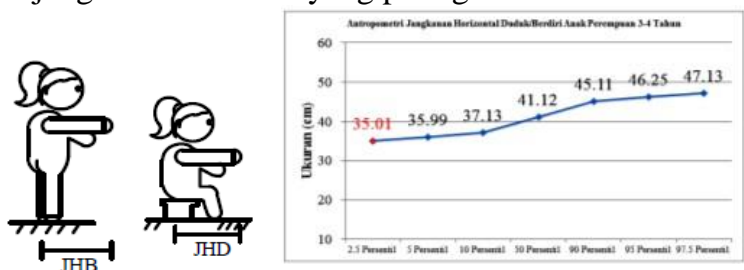

Gambar 20. Jangkauan horizontal duduk/berdiri anak perempuan 3-4 tahun.

Berdasarkan hasil perhitungan dari persentil jangkuan horizontal berdiri/duduk seperti Gambar 20, dapat digunakan untuk menentukan kedalaman permukaan meja. Menggunakan hasil dari 2.5 persentil yaitu $35.01 \mathrm{~cm}$ supaya anak dengan jangkauan yang paling pendek tetap dapat menggapai barang mereka. 

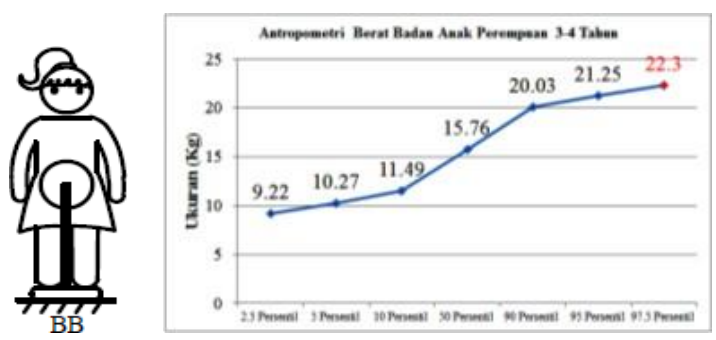

Gambar 21. Persentil berat badan anak perempuan 3-4 tahun.

Berdasarkan hasil perhitungan dari persentil berat badan seperti pada Gambar 21, dapat digunakan untuk menentukan minimum kekuatan kursi yang dapat digunakan di PAUD dari hasil 97.5 persentil yaitu 22.3 $\mathrm{kg}$ supaya kursi dapat menopang dengan kokoh. Berikut Merupakan Hasil Antropometri Anak Laki-Laki 3-4 tahun:
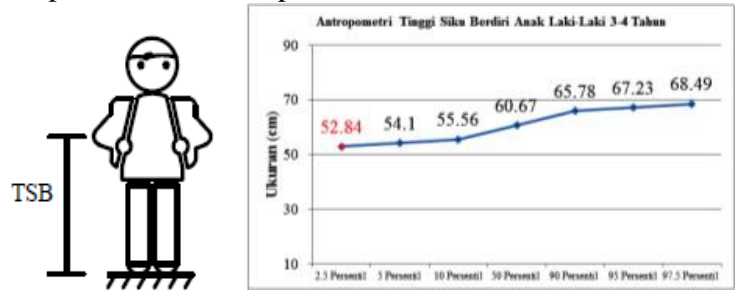

Gambar 22. Persentil tinggi siku berdiri anak laki-laki 3-4 tahun.

Berdasarkan hasil perhitungan dari persentil tinggi siku berdiri seperti Gambar 22, untuk anak laki-laki dapat digunakan untuk menentukan tinggi permukaan meja dalam posisi berdiri dengan ukuran dari 2.5 persentil yaitu $52.84 \mathrm{~cm}$ supaya anak dengan siku yang paling rendah tetap dapat meletakkan tangannya secara menyeluruh.
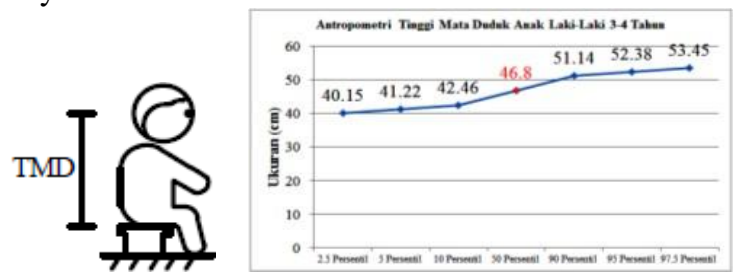

Gambar 23. Persentil tinggi mata duduk anak laki-laki 3-4 tahun.

Berdasarkan hasil perhitungan dari persentil tinggi mata duduk seperti Gambar 23, dapat digunakan untuk menentukan tinggi jarak pandang mata secara horizontal dalam keadaan duduk. Menggunakan hasil dari 50 persentil yaitu $46.8 \mathrm{~cm}$ supaya kedua belah pihak dapat melihat secara nyaman.
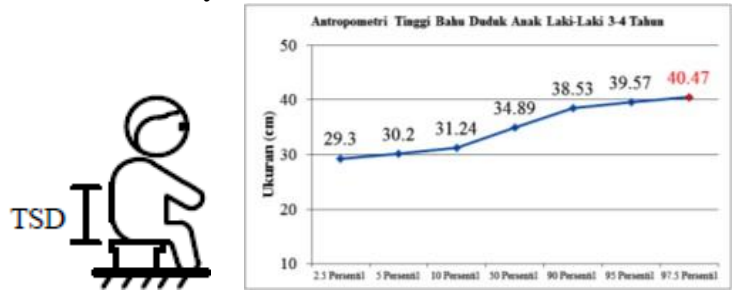

Gambar 24. Persentil tinggi siku duduk anak laki-laki 3-4 tahun.

Berdasarkan hasil perhitungan dari persentil tinggi siku duduk seperti pada Gambar 24, dapat digunakan untuk menentukan tinggi arm rest sebuah kursi. Menggunakan hasil dari 2.5 persentil yaitu $11.81 \mathrm{~cm}$ supaya anak dengan tinggi siku yang paling pendek tetap dapat meletakkan tangannya di atas arm rest secara nyaman.
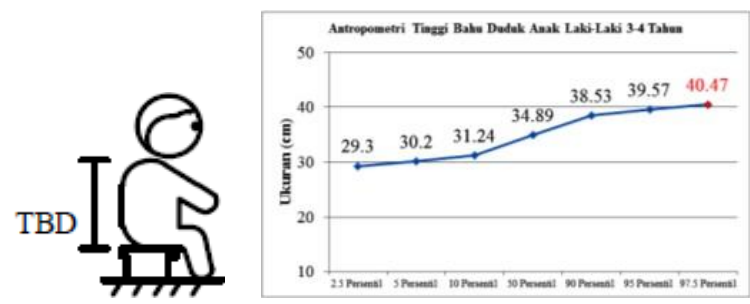

Gambar 25. Persentil tinggi bahu duduk anak laki-laki 3-4 tahun.

Berdasarkan hasil perhitungan dari persentil tinggi bahu duduk seperti pada Gambar 25, dapat digunakan untuk menentukan sandaran sebuah kursi. Menggunakan hasil dari 97.5 persentil yaitu $40.47 \mathrm{~cm}$ supaya anak dengan bahu yang paling tinggi tetap dapat duduk dan bersandar dari pantat hingga mendekati tulang leher.

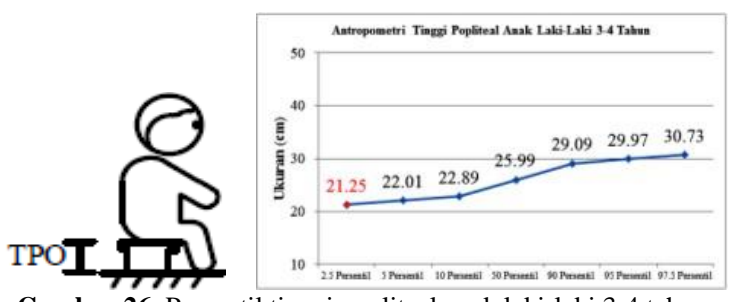

Gambar 26. Persentil tinggi popliteal anak laki-laki 3-4 tahun.

Berdasarkan hasil perhitungan dari persentil tinggi popliteal seperti pada Gambar 26, dapat digunakan untuk menentukan tinggi alas duduk dengan menggunakan hasil dari 2.5 persentil yaitu $21.25 \mathrm{~cm}$ supaya anak dengan tinggi popliteal yang pendek dapat duduk dengan ergonomis karena telapak kaki dapat menyentuh lantai secara menyeluruh.
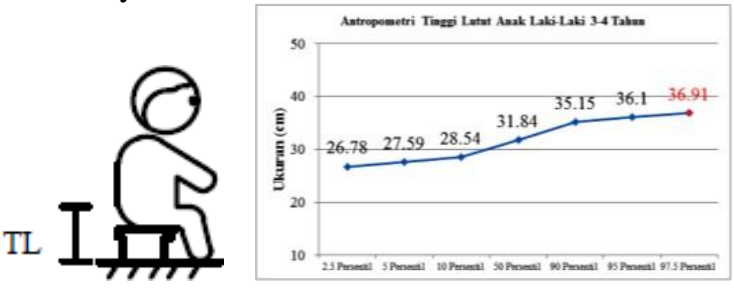

Gambar 27. Persentil tinggi lutut anak laki-laki 3-4 tahun.

Berdasarkan hasil perhitungan dari persentil tinggi lutut seperti pada Gambar 27, dapat digunakan untuk menentukan tinggi permukaan meja bagian bawah. Menggunakan hasil dari 97.5 persentil yaitu $36.91 \mathrm{~cm}$ supaya anak dengan lutut yang paling tinggi dapat meletakkan kaki mereka di bawah meja dimana lututnya tanpa membentur permukaan meja bagian bawah.
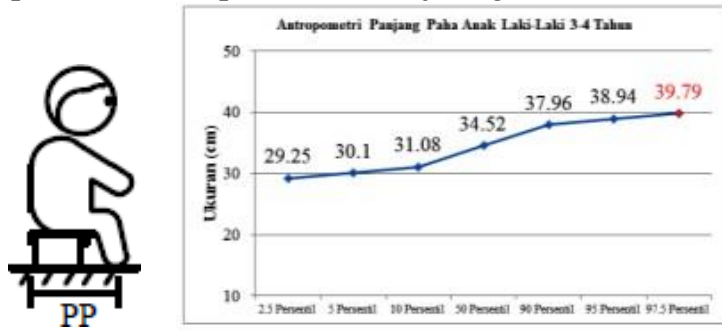

Gambar 28. Persentil panjang paha anak laki-laki 3-4 tahun.

Berdasarkan hasil perhitungan dari persentil panjang paha seperti pada Gambar 28, dapat digunakan untuk menentukan jarak kursi satu dengan kursi lainnya. Menggunakan hasil dari 97.5 persentil yaitu $39.79 \mathrm{~cm}$ supaya jarak antar kursi cukup luas sehingga kaki dapat diletakkan secara nyaman di antara jaraknya. 

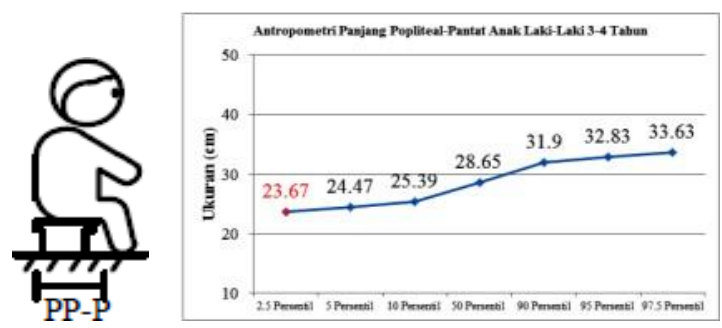

Gambar 29. Persentil panjang popliteal-pantat anak laki-laki 3-4 tahun.

Berdasarkan hasil perhitungan dari persentil panjang popliteal-pantat pada Gambar 29, dapat digunakan untuk kedalaman dudukan. Menggunakan hasil dari 2.5 persentil yaitu $23.67 \mathrm{~cm}$ supaya anak dengan panjang popliteal-pantat pendek dapat duduk secara nyaman karena anak tidak perlu duduk dengan kaki menggantung.

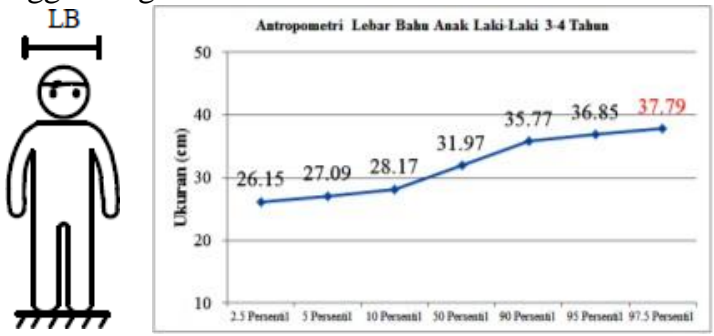

Gambar 30. Persentil lebar bahu anak laki-laki 3-4 tahun.

Berdasarkan hasil perhitungan dari persentil lebar bahu seperti pada Gambar 30, dapat digunakan untuk menentukan lebar sandaran kursi. Menggunakan hasil dari 97.5 persentil yaitu $37.79 \mathrm{~cm}$ supaya bahu yang paling lebar dapat ditopang secara menyeluruh.
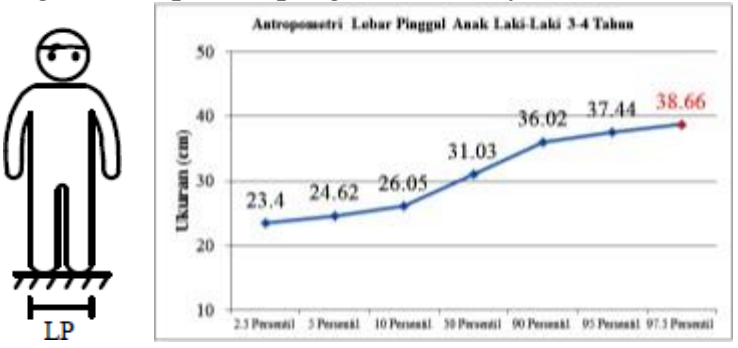

Gambar 31. Persentil lebar pinggul anak laki-laki 3-4 tahun.

Berdasarkan hasil perhitungan dari persentil lebar pinggul seperti pada Gambar 31, dapat digunakan untuk menentukan lebar alas duduk. Menggunakan hasil dari 97.5 persentil yaitu $38.66 \mathrm{~cm}$ supaya pantat terlebar dapat terwadahi secara menyeluruh.
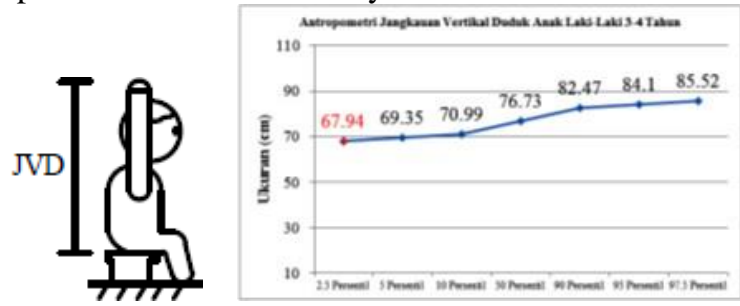

Gambar 32. Persentil jangkauan vertikal duduk anak laki-laki 3-4 tahun.

Berdasarkan hasil perhitungan dari persentil jangkauan vertikal duduk seperti pada Gambar 32, dapat digunakan untuk menentukan tinggi maksimal sebuah rak yang dapat digapai dalam posisi duduk. Menggunakan hasil dari 2.5 persentil yaitu $67.94 \mathrm{~cm}$ supaya anak dengan jangkauan paling pendek dapat menggapai rak yang paling atas.

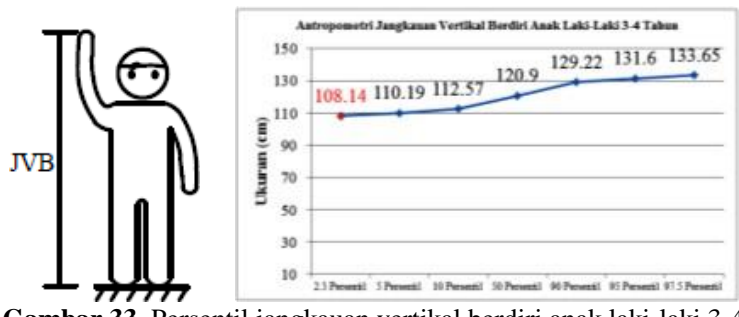

Gambar 33. Persentil jangkauan vertikal berdiri anak laki-laki 3-4 tahun.

Berdasarkan hasil perhitungan dari persentil jangkauan vertikal berdiri seperti Gambar 33, dapat digunakan untuk menentukan tinggi maksimal sebuah rak. Menggunakan hasil dari 2.5 persentil yaitu 108.14 $\mathrm{cm}$ supaya anak dengan jangkauan yang paling pendek tetap dapat menggapai rak paling atas dan menggambil barang mereka secara mandiri.

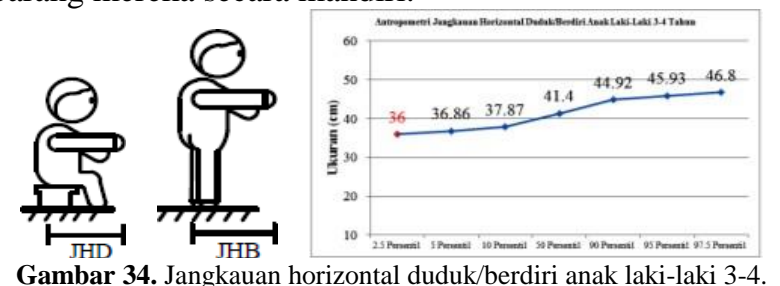

Gambar 34. Jangkauan horizontal duduk/berdiri anak laki-laki 3-4.

Berdasarkan hasil perhitungan dari persentil jangkauan horizontal duduk/berdiri seperti Gambar 34, dapat digunakan untuk menentukan kedalaman sebuah alas permukaan meja. Menggunakan hasil dari 2.5 persentil yaitu $36 \mathrm{~cm}$ supaya anak dengan jangkauan horizon yang paling pendek dapat menggapai barang mereka walau di ujung meja sekalipun.
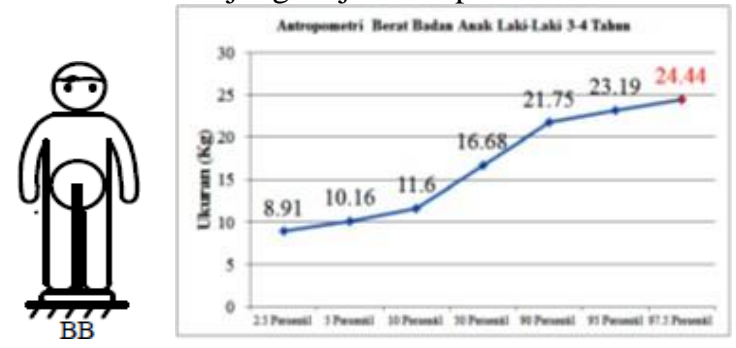

Gambar 35. Persentil berat badan anak laki-laki 3-4 tahun.

Berdasarkan hasil perhitungan dari persentil berat badan seperti pada Gambar 35, dapat digunakan untuk menentukan kekuatan minimum kursi di PAUD Siwalankerto. Menggunakan hasil dari 97.5 persentil yaitu $24.44 \mathrm{~kg}$ supaya anak dengan berat badan yang paling berat dapat duduk secara nyaman.

Berdasarkan hasil perhitungan data antropometri yang telah dijabarkan seperti di atas maka hasil tersebut dapat digunakan untuk menentukan ukuran mebel yang sesuai dengan anak usia dini 3-4 tahun seperti berikut: 
Hasimjaya: Kajian Antropometri \& Ergonomi Desain Mebel Pendidikan Anak

Tabel 1. Rekomendasi ukuran mebel anak perempuan 3-4 tahun.

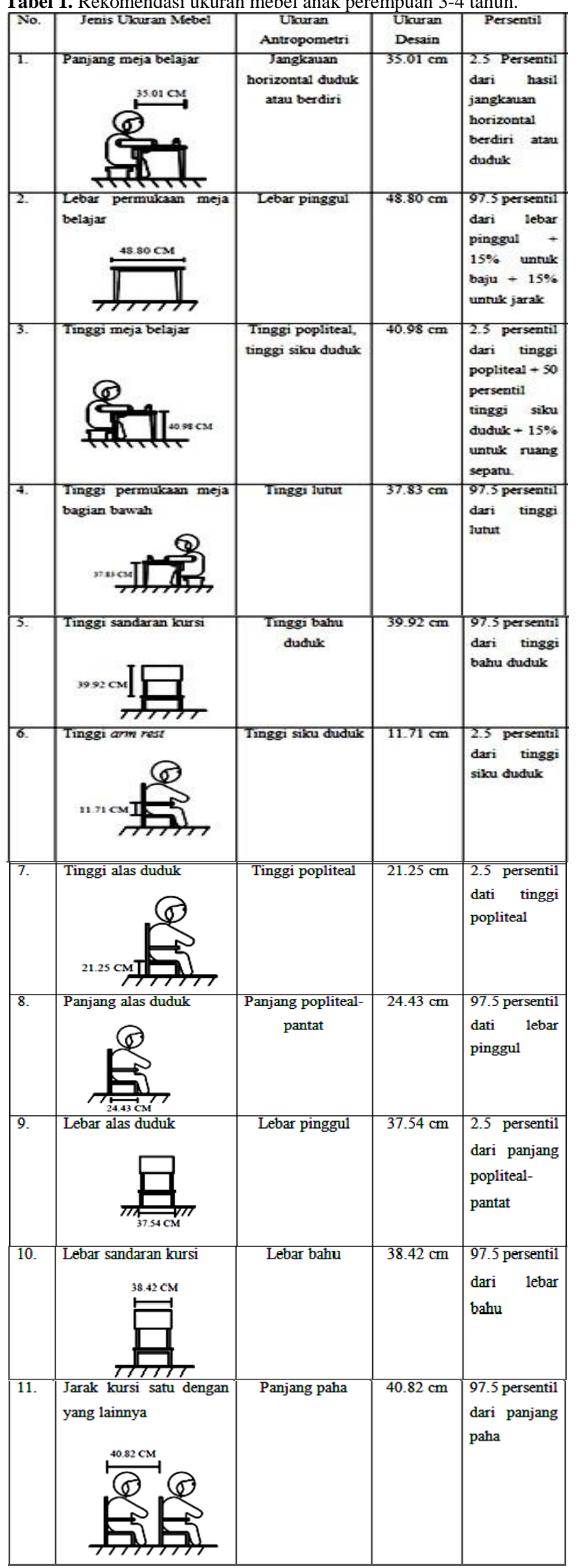

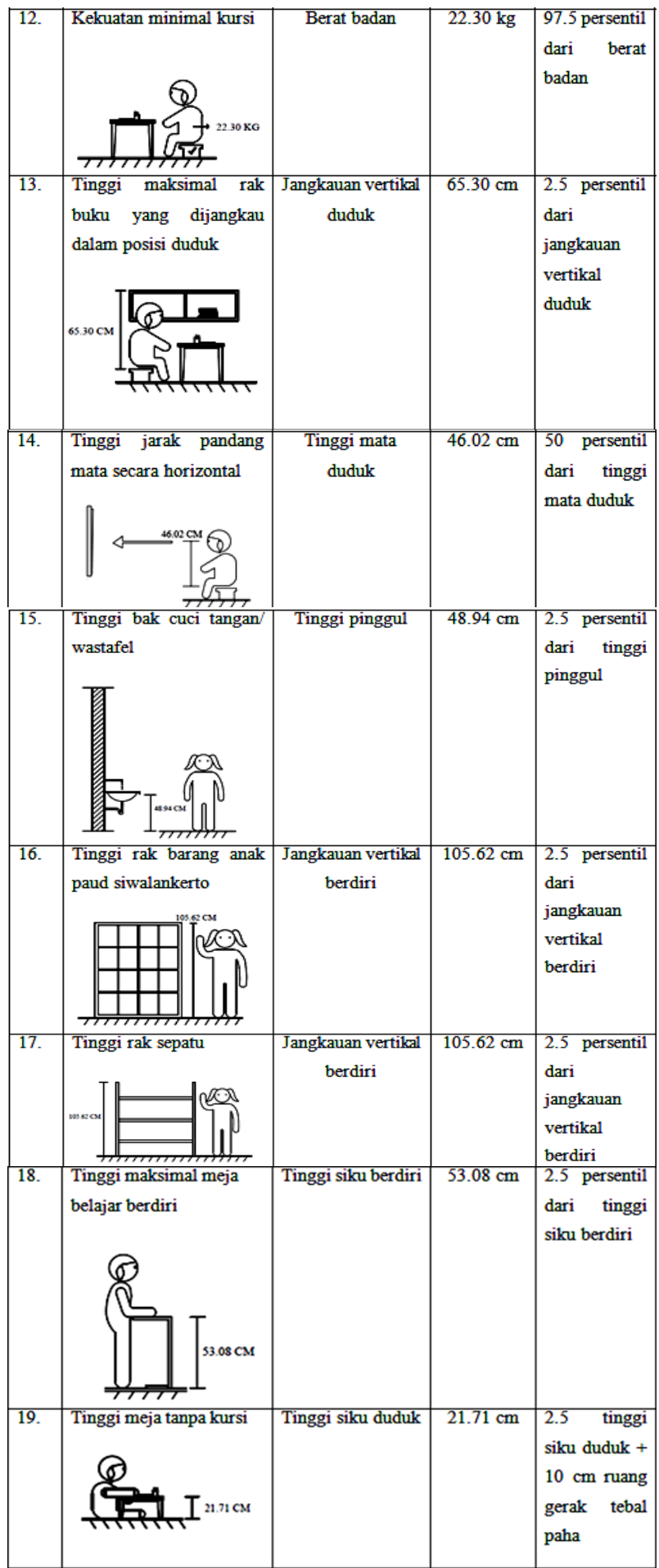

Tabel 2. Rekomendasi ukuran mebel anak laki-laki 3-4 tahun.

\begin{tabular}{|c|c|c|c|c|}
\hline No. & Jenis Ukuran mebel & $\begin{array}{c}\text { Ukuran } \\
\text { Antropometri }\end{array}$ & $\begin{array}{l}\text { Ukuran } \\
\text { Desain }\end{array}$ & Persentil \\
\hline 1. & $\begin{array}{l}\text { Panjang meja belajar } \\
36 \mathrm{CM}\end{array}$ & $\begin{array}{c}\text { Jangkauan } \\
\text { horizontal duduk } \\
\text { atau berdiri }\end{array}$ & $36 \mathrm{~cm}$ & $\begin{array}{l}2.5 \text { Persentil } \\
\text { dari hasil } \\
\text { jangkauan } \\
\text { horizontal } \\
\text { berdiri atau } \\
\text { duduk }\end{array}$ \\
\hline 2. & $\begin{array}{lll}\text { Lebar permukaan meja } \\
\text { belajar } \\
\\
& \\
& & \\
& & \\
& \end{array}$ & Lebar pinggul & $50.24 \mathrm{~cm}$ & $\begin{array}{lr}97.5 & \text { persentil } \\
\text { dari lebar } \\
\text { pinggul }+15 \% \\
\text { untuk baju }+ \\
15 \% \text { untuk } \\
\text { jarak }\end{array}$ \\
\hline
\end{tabular}




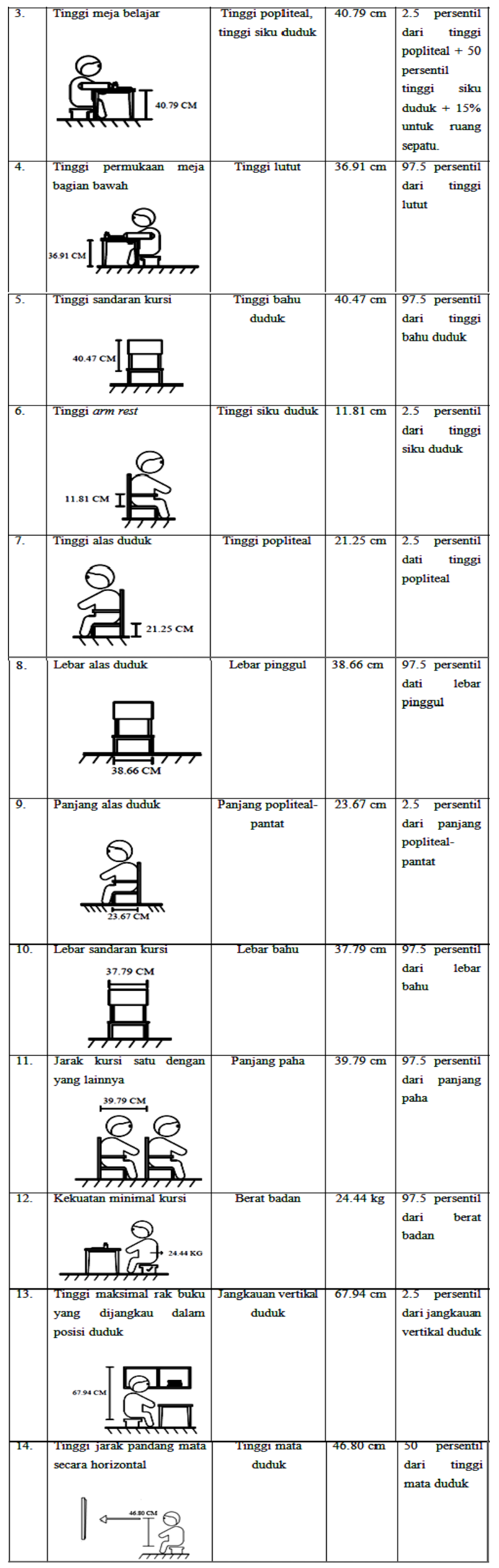

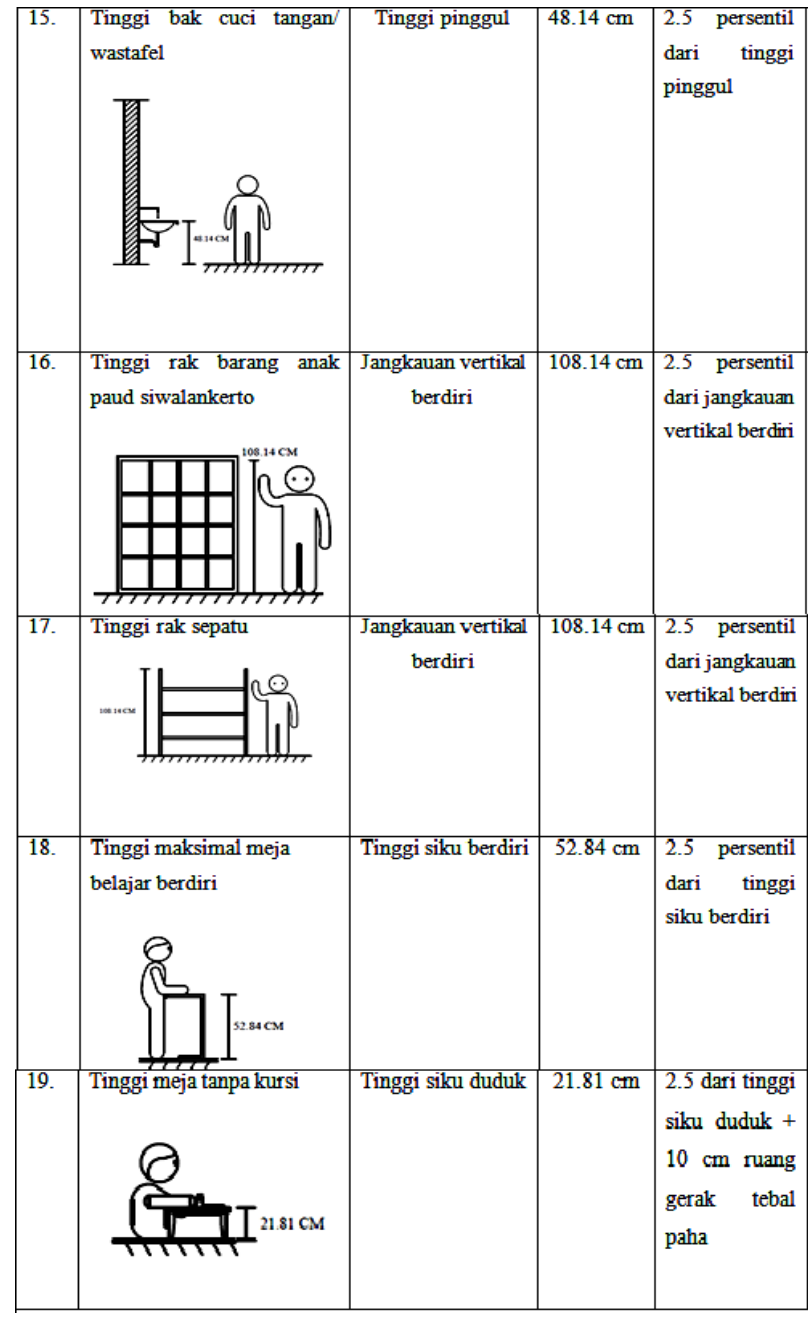

\section{SIMPULAN}

Berdasarkan analisa yang telah dilakukan maka dapat disimpulkan ternyata mebel yang ada di PAUD Siwalankerto untuk anak usia 3-4 tahun tidak cocok dengan penggunanya dan memiliki beberapa masalah terkait ergonomi sehingga memang perlu dikaji melalui bidang ilmu antropometri. Selain itu ternyata perbedaan umur dan jenis kelamin anak-anak juga sangat mempengaruhi besar kecilnya dimensi tubuh mereka sehingga secara otomatis juga mempengaruhi ukuran mebel yang digunakan. Dimana anak dengan umur yang lebih besar secara dominan memiliki ukuran tubuh yang lebih besar. Karena hal ini, maka dalam membuat ukuran mebel supaya ergonomis sebaiknya menerapkan hasil pengukuran yang sesuai dengan penggunanya yaitu anak usia dini 3-4 tahun karena mereka merupakan subjek yang paling sering berinteraksi dengan mebel-mebel tersebut sehingga harus sangat dipertimbangkan.

\section{REFERENSI}

[1] A. S. Harmastuti. "Perencanaan Dan Perancangan Interior Pendidikan Anak Usia Dini (Paud) Di Surakarta". Universitas Sebelas Maret. Surakarta., (2009) 27.

[2] W. D. Wijana. Konsep Dasar Pendidikan Anak Usia Dini. Banten : Universitas Terbuka (2014) 2. 
[3] www.comunityplaythings.com

[4] R. Siregar, L. N. Huda, A. J. M. Rambe. (2014, Juli). Perancangan Kursi dan Meja Berdasarkan Antropometri Pada Sekolah Dasar Swasta X. Jurnal Tenik Industri. [Online]. 3(1). pp. 24-30. Available :

http://id.portalgaruda.org/?ref=browse \&mod=view article \&article $=264386$

[5] E-learning Universitas Pembangunan Nasional. Metodologi Desain. Surabaya : Universitas Pembangunan Nasional (n.d.)3. Available : http://elearning.upnjatim.ac.id/courses/METODED ESAIN1/document/ METODOLOGI_DESAIN_25.pdf?cidReq=METO DEDESAIN1

[6] M. N. Aini, "Pengaruh Pendidikan dan Pelatihan (Diklat) Kearsipan Terhadap Profesionalisme Arsiparis di Bapusipda ( Badan Perpustakaan Dan Kearsipan Daerah) Se-Bandung Raya," Universitas Pendidikan Indonesia Bandung., (2013), Available:

http://repository.upi.edu/1300/6/S_PKR_0904108_ Chapter3.pdf

[7] N. Azizah, "Resume Materi Populasi dan Sampel Penelitian," thesis, Program Studi Pendidikan Matematika, Universitas Negeri Yogyakarta, Yogyakarta, (2016), Available :

http://petaniilmu.blogs.uny.ac.id/wpcontent/uploads/sites/7044/2016/11/RESUMEMATERI-POPULASI-DAN-SAMPELPENELITIAN.pdf

[8] Sugiyono. Metode Penelitian Kuantitatif dan R\&D. Bandung : Alfabeta (2012) 126.

[9] A. Widiastuti, "Data, Teknik Pengumpulan Data Dan Instrumen Penelitian.” presented at Yogyakarta Country University, Yogyakarta, Ind.

[10] M. Safran. Teknik Pengolahan dan Interpretasi Data. Selami IPS Edisi Nomor 21 Volume II. Jakarta: LIPI pres (2007) 203.

[11] Indonesia. Direktorat Jenderal Peningkatan Mutu Pendidikan \& Tenaga Kependidikan. Instrumen Pengawasan Sekolah. Jakarta : Author (2008) 24.

[12] Norfiza, Z. Infi. (2011). Perancangan Alat Belajar dan Bermain Yang Ergonomis Di Taman KanakKanak Islam Permata Selat Panjang. Jurnal Ilmiah Teknik Industri. [Online].(10)1. pp. 48-58. Available:http://journals.ums.ac.id/index.php/jiti/a rticle/view/1249/810.

[13] M. A. Latar, "Antropometri dan Aplikasinya Dalam Perancangan Fasilitas Kerja" presented at Esa Unggul University, Jakarta.

[14] H. Purnomo. Antropometri Dan Aplikasinya. Yogyakarta : Graha Ilmu (2013) 1-26,37.

[15] L. Herawati, T. A. Pawitra. (2013). Evaluasi Data Antropometri Anak- Anak Usia 4-6 Tahun Di Jawa Timur Dan Aplikasi Pada Perancangan Fasilitas Belajar Di Sekolah. Jurnal Ilmiah Teknik Industri. [Online]. (12)2. pp. 146. 13 November 2016.Available:

https://publikasiilmiah.ums.ac.id/bitstream/handle
/11617/4399/JITI-12-02-13

Linda\%20Herawati\%20-

$\%$ 20OK.pdf? sequence $=1 \&$ is Allowed $=y$

[16] Indonesia. Direktorat Pembinaan Pendidikan Anak Usia Dini. Norma, Standar, Prosedur, Dan Kriteria Pedoman Prasarana Pendidikan Anak Usia Dini. Jakarta : Author (2015) 34.

[17] Jamaludin. Pengantar Desain Mebel. Bandung : PT. Kiblat Buku (2007) 123.

[18] I. M. Sutajaya. (Mei 2007). " Peningkatan Profesionalisme Guru Melalui Pemahaman Terhadap Ergonomi Dalam Pembelajaran”. Jurnal Pendidikan dan Pengajaran Undiksha : 560-562. 3 April 2017. Available: https://www.google.co.id/url?sa=t\&rct=j\&q=\&esr $\mathrm{c}=\mathrm{s} \&$ source $=$ web $\& \mathrm{~cd}=48 \& \mathrm{cad}=\mathrm{rja} \& u a c t=8 \& \mathrm{ved}=$ 0ahUKEwjQr8b5gIrTAhUHSI8KHeM9Cv Q4KBAWCEgwBw\&url=http\%3A\%2F\%2Fpasca .undiksha.ac.id\%2Fimages\%2Fimg_item\%2F934. doc\&usg=AFQjCNFt71RNNjvVeEvNFE1 1EqrFsq67jg

[19] Indonesia. Direktorat Pembinaan Pendidikan Anak Usia Dini. Norma, Standar, Prosedur, Dan Kriteria Pedoman Prasarana Pendidikan Anak Usia Dini. Jakarta : Author (2014) 18. 